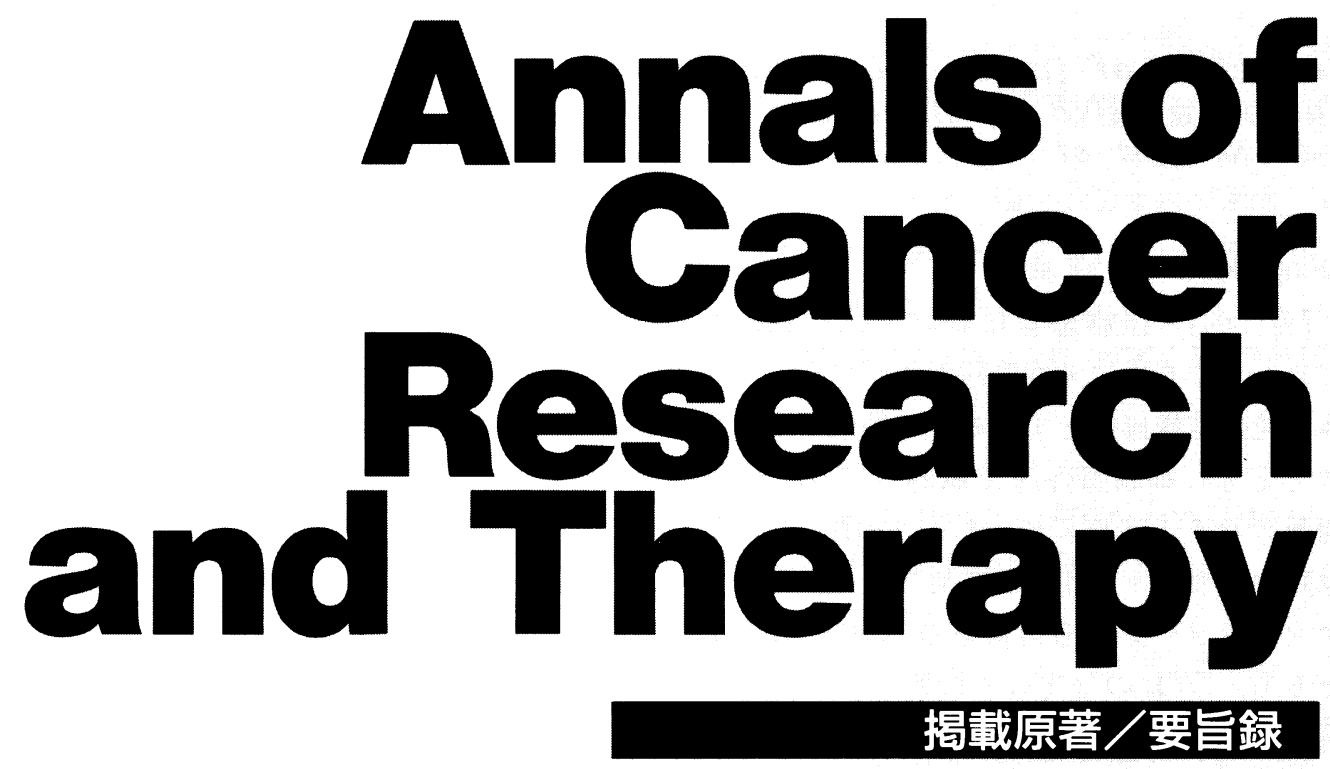

Ann Cancer Res Ther (Pub quart) Official Journal of the Japanese Society of Strategies for Cancer Research and Therapy 
Induction of tumor-specific cytotoxic $T$ lymphocytes by tumor necrosis factor- $\alpha$ (INF $\alpha)$ in cancer patients

Vol. 4, No. 2, p83 87

\section{Shingo Kameoka et al.}

【目的】担癌患者においては，TGF $\beta$ をは じめとする多くの免疫抑制因子が存在し，癌は生 体の免疫監視機構をすりぬけて増殖する。癌の進 行とともに細胞障害性 $\mathrm{T}$ 細胞 (CTL) の誘導は 困難になり，癌患者から CTL を誘導するために は新たなサイトカインが必要となる。そこで今回, マクロファージから分泌され T 細胞活性化作用 をもち，CTLの分化にも影響を与えることが知 られている $\mathrm{TNF} \alpha$ を用い，癌患者末梢血より CTL を誘導する系で TNF $\alpha$ が CTL の誘導に与 える影響について検討した。

【方 法】6人の癌患者により，Ficoll-Hypaque を用いた比重遠心法により末梢血単核球を分 離し，自己癌細胞または当科で樹立した HLA class-I の明らかな癌細胞株と50：1の割合で混 合培養（MLTC）を行い, MLTCの最初に100, $1,000 / \mathrm{ml}$ の $\mathrm{TNF} \alpha$ を加え，3 日間培養をつづ けた。その後 $\mathrm{TNF} \alpha$ を除き, $1 \mu \mathrm{g} / \mathrm{ml}$ 固相化 抗 CD 3 抗体と $1,000 \mathrm{U} / \mathrm{ml}$ IL-2でさらに3〜7 日間刺激した。その後は抗 CD 3 抗体を除き 500 $\mathrm{U} / \mathrm{ml}$ のIL-2を含む培養液で培養を行った。 CTL 活性は細胞が十分増殖した $3 \sim 4$ 週間後に 4 時間 ${ }^{51} \mathrm{Cr}$ 放出試験にて測定され，フローサイ トメトリーで $\mathrm{T}$ 細胞の表面マーカーを測定した。

【結 果】(1) 腫瘍リンパ球混合培養時にTNF $\alpha$ を加えなかった場合，6例中 4 例にCTL 活性が 誘導できなかった。しかし，TNF $\alpha$ を加えるこ とによって，CTL 活性が誘導できなかった 4 例 中 2 例にCTL 活性が誘導できた。この活性は
$\mathrm{TNF} \alpha$ の濃度依存性に増強され, $1,000 \mathrm{U} / \mathrm{ml}$ の 濃度でもっとも活性が高かった。 TNF $\alpha$ を加え なくても活性の高かった 2 例に $\mathrm{TNF} \alpha$ を加えて も活性への影響はなかった（Fig. 2)。(2) CTL 活 性が得られた 2 例で HLA の異なる同種癌細胞に 対する抗腫瘍活性を測定すると，それらの細胞に 対しても活性の増強が得られた (Fig. 3)。(3) $\mathrm{CTL}$ の増殖は $\mathrm{TNF} \alpha$ の濃度依存性に増加し, $\mathrm{TNF} \alpha$ 無添加群では 3 週間後に17倍であったの に対し，100U/ml，1,000U/mlの濃度でそれぞ れ23倍，34倍まで増加した（Fig.4)。(3)フロー サイトメトリーの検討では, 活性の増強が得られ た症例で CD8+Leu15-細胞の割合が増加したが, 活性の増強は得られなかった症例では $\mathrm{CD}^{+}$ Leu15一細胞はまったく増加しなかった（Table 4).

【考察】進行癌患者で通常の MLTC のみで CTL が誘導できる確立はかなり限られている。 今回の検討では, TNF $\alpha$ は CTL 活性の誘導で きなかった患者の半数に活性を誘導できた。活性 の誘導できなかった症例は癌が進行し，栄養状態 のわるい傾向があった。TNF $\alpha$ は HLA の異な る同種癌細胞に対する抗腫瘍活性も増強するため, CTL 活性の腫瘍特異性を高兴用はないもの と考えられた。CTL療法への TNF $\alpha$ の併用は 有用と考えられたが，腫瘍特異性の高いCTL を 誘導するため，他のサイトカインの有用性につい てもさらに検討をつづける必要がある。

(亀岡信吾, 東京女子医科大学第二外科学教室)

\section{Breast cancer only detected by thermography; A case report Vol. 4, No. 2, p89 90}

Takao Yokoe et al.

症例報告：サーモングラフィーで発見された乳癌 の 1 例
サーモグラフィーのみで発見された乳癌症例を 報告する。

患者は50歳の女性で，左乳房の硬結を主訴に当 
院を紹介された。来院時, 左乳房全体に多数の弾 性軟な硬結を触れた。乳房撮影では腫瘤影はみら れなかった。サーモグラフィーでは乳房全体に異 常熱血管像が，内側上方に高温域，および乳頭高 温がみられ，いずれも冷却抵抗を示した。このた 高温域の内側上方の乳腺を生検した。切除した 乳腺のなかに周囲に浸潤する $0.8 \times 0.7 \mathrm{~cm}$ の腫瘤 を認めた。組織型は硬癌で ER, PgR は陽性で
あった。乳腺の追加切除を含めた乳房温存手術を 行い, 残存乳房に50Gyの照射を行った。リンパ 節転移はなかった。

サーモグラフィーは，機能的診断法であり，乳 房撮影や超音波検査でとらえられない早期乳癌を 発見できる可能性が示された。

(横江隆夫, 群馬大学医学部第二外科学教室)

\section{Immunohistochemical analysis of advanced colon cancer after lentinan administration; Emperipolesis of tumor-infiltrating lymphocytes Vol. 4, No. 2, p91 97}

\section{Nobuaki Sakamoto}

レンチナンの結腸進行癌に対寸る免疫組織学的 効果, 特に間質内浸潤 Tリンパ球と光顕レベル での emperipoletic T lymphocyte について検討 した。

【対象と方法】対象は, 結腸進行癌 Dukes B, Cの高分化ないし中分化型腺癌57例である。その 内訳は, 対照群29例, レンチナン投与群 28 例（2 $\mathrm{mg} 2$ 回投与群10例， $4 \mathrm{mg} 2$ 回投与群 8 例， 8 mg 2 回投与群10例) である。レンチナン投与群 は，治癒切除術14日前と7日前にそれぞれ点滴静 注した。新鮮凍結標本およびホルマリン固定標本 を用い，間質内浸潤 Tリンパ球とその Subset (CD4, CD8), 光顕レベルでの emperipoletic T lymhocyte とその subset (CD4, CD8), HLAclass I $と$ HLA-DR の表出率の変化について比 較検討した。

\section{【結 果】}

(1) 年齢, 性, 組織型, 進行度において, 各群 間に統計的偏りを認めなかった。

(2) レンチナン投与により間質内 Tリンパ球浸 潤の艺進を認め, 対象群に比し $4 \mathrm{mg}$ 群および 8 $\mathrm{mg}$ 群において有意に増加した $(\mathrm{P}<0.05)$ 。

(3)その subsetをみると，CD4は各群間に差 を認めなかったが，CD8は投与量依存的に増加し， $8 \mathrm{mg}$ 群において対象群に比して有意差が認めら れた $(\mathrm{P}<0.05)$ 。
(4) HLA-class I の表出率は，レンチナン投 与群と対象群ともに約 $80 \%$ 症例が strong であ り，両群間に差を認めなかった。

(5) HLA-DRの表出率はレンチナン投与に よって有意に増加した $(\mathrm{P}<0.05)$ 。

(6) 光顕レベルでの emperipolesis は, 対象群 に比し $2 \mathrm{mg}$ 群， $4 \mathrm{mg}$ 群，8 mg 群において有 意に増加した $(\mathrm{P}<0.05)$ 。

(7) Emperipolesis を呈しているリンパ球 subset（CD4，CD8）をみると，そのほとんぼは CD8陽性細胞であり, CD4陽性細胞は癌細胞腺管 周囲に多数存在するものの, empeipolesis を呈 しているものは少なかった。なお，CD8とCD11b の二重染色にて emperipolesis を呈している CD8 の陽性細胞は, cytotoxic $\mathrm{T}$ lymphocyteである ことを確認した。

【考 察】 Cytotoxic T cell, Natural killer cell なぞのリンパ球が癌細胞を障害する場合, 癌 細胞膜との接着は必須である。また, 光顕レベル での emperipolesis は基底膜の存在の有無にかか わらず，リンパ球と癌細胞膜との接着, あるいは 接着を経由したことを意味する。したがって，レ ンチナン投与により光顕レベルでの emperipoletic T lymphocyte が増加することは，レン チナンに抗腫瘍作用があることを示寸所見である と推察される。

(坂本啓彰, 東京医科大学外科学第三講座) 


\section{Association of the $H L A-D P B 1 * 0901-D R B 1 * 1502$ haplotype with stomach cancer in Japanese \\ Vol. 4, No. 2, p99 102}

\section{Fumiya Obata et al.}

【目 的】HLA はヒトに扔引る免疫応答遺伝 子であり，かつきわめていちじるしい多型性を示 す。したがって HLA 型によっては，結合できる 癌抗原ペプチドの種類に差が存在すると想定され る。その場合 HLA は，癌発症に影響を及ぼす遺 伝因子の 1 候補となりうるだろう。これまで報告 されている血清学的タイピングによる研究では, HLA 型と胃癌発症との相関について明瞭な結論 は得られていない。また，細胞学的タイピングを 必要とする HLA-DP 型についてはまったく報告 されていない。筆者らは，血清学的タイピングに より信頼性・精度がすぐれ，かつ簡便にDPタイ ピングも可能な DNA タイピング法を用い，胃癌 患者に打ける HLA 遺伝子型の解析を行った。

【方 法】東海大学病院の胃癌患者 186 人（男 117人，女69人）を対象とした。患者末梢血から 得たゲノム DNA を鋳型とし，ポリメラーゼ連鎖 反応 $(\mathrm{PCR})$ による遺伝子増幅で DPB1および DRB 1 遺伝子を増幅した。DPB1解析は，第11 回国際組織適合性ワークショップ (11th IHWS) で配られた primer と26種の SSOP 用いて行い, 20 種の DPB1遺伝子型に分類した。DRB1解析は, 筆者ら自身が考案した primer と29種の SSOP 用い，31種の DRB1型に分類した。患者群につい て各遺伝子型の頻度を算出し，11th IHWSにお いて求められた日本人健常対照群の頻度と比較し た。統計学的有意性の検定は Fisher の直接確率 比較で行った。

【結 果】DNA タイピング法により胃癌患者 群186人における各 HLA-DPB1型の遺伝子頻度 を求め, 健常対照群と比較した。その結果,
DPB1*0901の頻度が胃癌患者群では26.9\%であ り，健常対照群における16.5\%にくらべて有意に 高いことがわかった（相対危険率=1.86, $\mathrm{P}<$ 0.003 , corrected $\mathrm{P}<0.05)$ 。つ ぞに, HLA DRB 1 遺伝子頻度について解析した結果, DPB1*1502の頻度が胃癌患者群では26.9\%であ り，健常対照群における17.6\%にくらべて高い傾 向がみられた（相対危険率 $=1.72 ， \mathrm{P}<0.006$, corrected $\mathrm{P}<0.15)$ 。さらに患者群において， DPB1*0901と DRB1*1502の両方をもつ患者は45 人 $(24.2 \%)$ 存在し，この割合は健常対照群にお

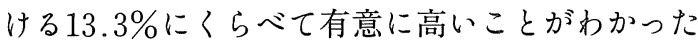
$(\mathrm{P}<0.003)$ 。

【考 察】この研究で筆者らは，胃癌患者群に HLA-DPB1*0901-DPB1*1502ハプロタイプが高 頻度に検出されることをはじめて明らかにした。

癌発症とDPについては，ホジキン病についての 報告があるのみである。興味深いことに，胃癌と 相関するDPB1*0901は，日本人に和ける shorter remission duration 型のホジキン病とも相関する ことが報告されている。

日本人集団に扔いては，DPB1*0901は DQB1* 0601 おるび DRB $1^{*} 1502$ と比較的強い連鎖不平衡 を示す。胃癌患者群でも，DPB1*0901と DRB1* 1502がハプロタイプとして高頻度に検出された。 したがって現在のところ，胃癌発症にDP，DR のうちどちらがより強く関与するのかを結論する ことはできない。このハプロタイプに連鎖する他 の HLA 遺伝子，あるいはペプチドの生成・運搬 に関わる DM，LAMP，TAP 遺伝子のいずれか が真の関与遺伝子である可能性も考えられる。

(小幡文弥, 北里大学医学部医療衛生部免疫学教室) 


\section{Patterns of recurrence of gastric cancer following curative gastrectomy depends on adjuvant chemotherapy \\ Vol. 4, No. 2, p103 107}

Sumitaka Arima et al.

北部九州の21施設より集計された Stage II, III, IVの組織学的に治癒切除された胃癌症例 163 例に対して, 術後補助化学療法として MMC+ Futraful（FT 群）とMMC+UFT(UFT 群) の 2 群間比較を封筒法により行った。

7 年生存率では, UFT 群 (66.7\%) は FT 群 (44.8\%) に比し有意に高い生存率を示した（P =0.04)。また，低分化型腺癌に打いて，UFT 群の生存率が有意に高かった。再発形式別に検討 すると，FTにくらべUFT が特に腹膜再発を強 く抑制している傾向がみられ，低分化腺癌に腹膜
再発が多いことを考え合わせると, UFT 群の 7 年生存率が有意に高いことの原因ではないかと推 察される。

再発率扔よび再発危険率は, UFT 群がFT 群 より低くなる傾向がみられたが，有意の差ではな かった。

再発時期を検討すると，FTおよび UFT 群と もに約 $70 \%$ が 2 年以内に再発を示しており，術後 の維持療法は少なくとも 2 年間は再発抑制のため に必要なことが示唆された。

(有馬純孝, 福岡大学筑紫病院外科)

\section{Prognostic value of DNA ploidy and proliferative activity in gastric carcinoma \\ Vol. 4, No. 2, p109 112}

Toshio Imada et al.

胃癌の予後予測因子として, 臨床的または病理 学的なステージ分類がもっとも用いられている。 しかし, 最近は数多くのモノクローナル抗体が作 成されるようになって，これらを用いた研究が盛 んに行われ，治療成績との関連性が検討されるよ うになってきた。

【目的】今回，胃癌症例において核 DNA 量

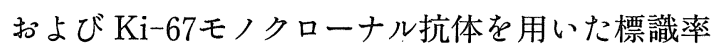
が予後を規定する因子として有用かぼうかを明ら かにすることを目的とした。

【対象と方法】胃癌切除症例102例を対象とし, 新鮮切除標本を用いて核 DNA ploidy pattern $\varepsilon$ Ki-67 labeling index を求め, 臨床病理所見およ び生存率との関係を比較検討した。DNA ploidy patternの測定はFACScan 用いて測定，解析 した。Ki-67 labeling index は免疫組織染色法 （ABC 法）を用いて染色し，1,000個の腫瘍細胞 に対する染色陽性細胞の率を求めた。
【結 果】

(1) DNA ploidy pattern は39.2\%が diploid pattern を示し, $60.8 \%$ が aneuploid pattern を 示した。

(2) DNA ploidy pattern は性, 年齢, リンパ 節転移の有無, 漿膜浸潤の有無, stage と関連が なかった。

(3) 分化型は，低分化型に比し DNA aneuploid の率が有意に高率であった。

(4) Ki-67 labeling index は12.9\%から56.9\% を示し，平均 $27.5 \%$ であった。

(5) Ki-67 labeling index $は$ aneuploid tumor において，より高率であった。

(6) Ki-67 labeling index はリンパ節転移, 漿 膜浸潤, stage と関連性が認められた。

(7) Diploid tumorの 3 年生存率は $68.5 \%$ と aneuploid tumorの $45.0 \%$ ๖も有意に良好で あった。

(8) Ki-67 labeling index が20\%以下の症例の 生存率は $20 \%$ 以上の例よりも良好であった。 
【考察】胃癌のDNA ploidy pattern や $\operatorname{BrdU}$ p PCNA なとの増殖能が治療成績と関連 性をもつかに゙うかの研究数多くあるが，一定の 見解に達していないのが現状である。この不一致 の原因となるものは，測定材料の違いと癌自身の もつ heterogeneityによると考えられる。
筆者らは，新鮮材料の全層切片を用いて prospective に検討し， 3 年間の経過観察を行った結 果，胃癌症例において核 DNA 量および $\mathrm{Ki}-67$ labeling index は, 重要な予後予測因子であると 考えられる結果を得な。

(今田敏夫，横浜市立大学医学部第一外科学教室)

\section{Relationship between expression of neuron-specific enolase and DNA content in human pancreatic carcinoma \\ Vol. 4, No. 2, p113 116}

Haruhiko Nagami et al.

【目的】筆者らはこれまでに，神経腫瘍にお いて特異的であるとされてきたneuron-specificenolase (NSE) が膵管癌においても免疫組織学 的に発現することを報告してきたが，この膵管癌 における NSE 発現性が生物学的悪性度の指標で ある腫瘍細胞核中 DNA 量とどのような関連を有 するかについての検討を膵管癌41症例について 行った。

【対象と方法】島根医科大学第一外科にて1982 年から93年までに外科的切除された膵管癌 41 症例 を対象とした（組織型の内訳：乳頭腺癌 2 例, 管 状腺癌 30 例, 粘液癌 3 例, 粘液囊胞腺癌 3 例, 脺 管内乳頭腺癌 3 例)。

ホルマリン固定後のパラフィンブロックから癌 部を含む $4 \mu \mathrm{m}$ の切片を作成後に, NSE 免疫組 織化学的染色（SAB 法）を行い，NSE 発現性を 検討すると同時に, 癌部を含む同様の切片を用い て Feulgen 染色しコンピューターg 画像解析装置 (cell analysis system: CAS) を用い約200個の 腫瘍細胞核の DNA histogram を作成し，DNA ploidy pattern, DNA index (D.I), histogram における tetraploid $(4 \mathrm{c})$ 以上の腫瘍細胞の出現率 (4c exceeding rate (\%) : 4c ER) を求め，先の NSE 発現性との関連について検討した。数值は mean $\pm \mathrm{SD} て ゙$ 表現し, 統計学的処理は Students t test 用い $5 \%$ 以下を有意差ありと判定した。
【結 果】（1）. NSE 発現性と DNA ploidy pattern との関連

膵管癌41例中21例（51.2\%）にNSE の免疫組 織化学的発現を認めた。また，NSE 発現例21例 中 diploid pattern 8 例 (38.1\%), aneuploid patternは12例（61.9\%）であったのに対し， NSE 非発現例では diploid pattern12例 (60.0\%), aneuploid pattern 8 例 $(40.0 \%)$ \& NSE発現例において aneuploid patternが多い 傾向にあった。

（2） NSE発現性とDNA index との関連 NSE 発現例の D.I は1.80 $00.70, N S E$ 非発現例 のD.I は1.58土0.69であり，NSE 発現例におい て D. I が高値であった。

（3） NSE 発現性と 4c ER との関連

NSE 発現例の4c ER は20.40土11.68\%，NSE 非発現例の4c ER は13.17 $48.09 \%$ と, NSE 発現 例の $4 \mathrm{c}$ ER は有意 $(\mathrm{P}<0.05)$ に高值を示した。

【結＼cjkstart語】膵管癌における NSE 発現は $51.2 \%$ に認められたが，このNSE 発現症例の腫瘍細胞 核 DNA 量の計測では tetraploid（4c）以上を示 す生物学的悪性度の高い細胞の出現率が高值で あった。したがって，NSE 発現性は核DNA 量 から判定すれば，膵癌における生物学的悪性度の 指標になる可能性が考えられた。

(長見晴彦，島根医科大学第一外科学教室) 
Relationship between DNA content and argyrophilic nucleolar organizer regions of tumor cells in bile duct cancer

Vol. 4, No. 2, p117 119

Haruhiko Nagami et al.

AgNOR カウントは, 細胞増殖能と密接な関連 がある一方で，イメージサイトメトリーやフロー サイトメトリーを用いたDNA 量（腫瘍細胞核 中）は各種悪性疾患の予後を判定するうえで有効 な方法である。

今回の検討では，外科的治療後のパラフィン固 定標本を用い，14例の胆管癌（男性 7 例，女性 7 例) の腫瘍細胞核中 AgNOR カウントおよび核 DNA 量について検討した。AgNOR カウントお よびAgNOR 面積は銀染色（Ploton らの方法に 準じ）によって行い，CAS200 Image Analysis System 用いて, 約 200 個の腫瘍細胞の平均 AgNOR カウントおよび面積を求めた。DNA 量
についてはQuantative Ploidy Analysis Program を用いて算出した。

約 200 個の腫瘍細胞核の平均 DNA 量の histogram から, (1) DNA ploidy パターン, (2) diploid rate (2c rate), (3) tetra ploid 以上 $(4 c+$ rate) を算出した。

Aneuploid 腫瘍の AgNOR カウントおよび腫 瘍細胞面積は, Diploidのものにくらべ有意に $(\mathrm{P}<0.05)$ 高值であった。また，Ag NORカウ ントと $4 \mathrm{c}+$ rate との間には相関を認めた。

以上のことから，胆管癌におけるDNA ploidy およびAgNOR カウントは, 予後判定上有用で あると考えられた。

(長見晴彦, 島根医科大学第一外科学教室) 